\title{
THE COMPARISON OF HEROINE'S JOURNEY IN BRAVE MOVIE (2012) AND MOANA MOVIE (2016)
}

\author{
Gita Mutiara Ramadhanty \\ UIN Sunan Gunung Djati, Bandung, gmramadhanty114@gmail.com
}

\begin{abstract}
The aim of this research is to discuss the comparison of the heroine's journey in Brave movie (2012) and Moana movie (2016). To analyze both of them, the researcher uses the theory of hero's journey by Christopher Vogler. Hero's or heroine's journey is a passage and stages about growth which must be passed successfully then could be called as a hero or heroine. Not only analyze the hero's journey, but also compare it by using comparative literature theory. This research is designed as a literary criticism. The method used in this research is comparative literature method. The results of the research indicate that the heroine in Brave and Moana movie, both of the heroine have gone through several stages in heroine's Journey. There is one difference in the two movies when viewed from the heroine's journey. From twelve hero's journey by Vogler, the heroine in Brave movie goes through 9 stages of hero's journey. Meanwhile the heroine in Moana movie passed 10 stages of the hero's journey and it indicates that Moana's main character represents a more heroine than Brave's main character.
\end{abstract}

Keywords: Comparative Literature, Movie, Hero's Journey.

\section{INTRODUCTION}

Popular fiction is a part of popular literature. It is necessary to know about genre in popular fiction since readers have different kind of taste in reading. Fiction has many types of genres such as romance, adventure, mystery, western hard-boiling detective, and melodrama. One of many genres in fiction which going to be discussed in this research is Adventure. We can call the adventure story as the action story because it contains many actions of the hero who face the obstacles or dangers to complete moral missions and other important thing (Cawelti, 1976, p. 39). The main character in adventure stories is called a Hero. Hero is a character whom willing to sacrifice their life for saving the world. The other word, a hero is a protagonist of a story because many people usually admire them (Hourihan, 1997, p. 39). Hero is known as character who saves the world. He always sacrifices himself to face some obstacles or dangers to achieve his goals. The difference between hero and heroine is their sex identity- hero refers to a man while heroine refers to a woman.

There are so many animation movies nowadays. Usually, those movies are included to children's literature -an easy to read or watched stories written for children such as fairy tales, lullabies, fables and folk songs. But nowadays animation movies not only watched by children but also watched by every people. There are so many studios that produced animation movies such as Pixar Animation Studio from US, Disney Animation Studio from US, Dreamwork Animation Studio from US, Studio Ghibli from Japan, Blue Sky Studio from US and many others. The researcher has searched the famous animation studios in Google and the first 
studios which came out is Pixar and then Disney Animation Studios. This research uses Brave and Moana movie as an object to analyze. Moana is an animation movie by Ron Clements and John Musker, produced by Disney Animation Studio on November 2016. While Brave is an animation movie by Brenda Chapman and Mark Andrews, produced by Pixar Animation Studio.

Typically, lot of Disney's movies are about princess stories or it can be called as Disney formula such as Cinderella, Rapunzel, Snow White and many others. However, Brave and Moana focus on the search of the main character's identity and included as adventure stories. While Brave is the first Pixar animation which the main character is a girl. That makes the researcher want to explore more about heroine in animation movies especially in Pixar and Disney Animation Studios. Besides, both of them are animated movies that are usually watched by children, the researcher will find out what stages they are going through. Which stage the heroine faces will be seen after analyzing this research. We can see the differences and the similarities after analyzing this research.

\section{LITERATURE REVIEW}

Hero's or heroine's journey is a stage about growth and passage each stage of journey must be passed successfully then become a hero or heroine. According to Vogler, there are twelve stages to compose the journey; ordinary world; call to adventure; refusal of the call; meeting with the mentor; crossing the first threshold; test, allies, enemies; approach to the inmost cave; the ordeal; reward; the road back; the resurrection; and return with the elixir (Vogler, 2007, pp. 83-228).

1. Ordinary World

The ordinary world is the first step in the departure of a hero that shows the natural habitat and ordinary life of a hero. In this step, it is usually the introductory stage of life before becoming a hero.

2. The Call to The Adventure

This stage can also be called a trigger for the hero to carry out heroic actions. There will be something in the form of a message or a messenger who comes and makes the hero feel called to solve the problem that is happening.

3. Refusal to The Call

Some hero will refuse the call to the adventure. They have doubts about doing it and it is natural for them to avoid the call for the first time.

4. Meeting With The Mentor

The next stage of this hero's journey is meeting with the mentor -someone who protects, guides and even gives magical gifts to heroes.

5. Crossing The First Threshold

In this stage hero will be faced with changes that are so contrasting with his previous life. This activity is generally preceded by outside pressure that makes the hero pass the first gate to enter new territory and start his adventure.

6. Test, Allies, Enemies

The function of this stage is for testing. Placing heroes in several trials and challenges to face the real challenges ahead.

7. Approach to The Inmost Cave

The next step in the hero's journey is Approach to the inmost cave. This stage is an intermediate region between the border and the very center of the Hero's Journey.

8. The Ordeal

The Ordeal Stage is the stage in the middle of the story where the hero must face the biggest challenge or fear. 
9. Reward

This stage is the stage where the hero gains treasure or something value, which he gets after facing death or the greatest fears.

10. The Road Back

In this phase, the hero is forced to make a difficult choice. Usually, the hero will be offered to stay in the special world or return to the ordinary world.

11. The Resurrection

In order for the story to be more complete, this stage is where the hero experience the most challenging stage of passages. This stage exists because the audience needs a moment where the hero dies and reborn, almost the same as the supreme ordeal but different.

12. Return with Elixir

This stage is the final reward on the hero's journey. Hero or heroine will come back to the place he or she used to, back to the ordinary world.

\section{METHOD}

This research uses literary criticism as a ground design, "Criticism, or more specifically literary criticism, is the overall term for studies concerned with defining, classifying, analyzing, interpreting, and evaluating works of literature." (Abrams, 2009, p. 61). According to Abrams on Dian Nurrachman (Nurrachman, 2017, p. 6) there are several approaches in literary criticism such as Mimetic, Pragmatic, Expressive and Objective. From those approaches, this research takes objective approach. "Objective is the approach that treats literary work as something stands free from what is often called 'extrinsic' reference" (Nurrachman, 2017, p. 7). By using objective approach, this research is analyzed in which literary work is viewed from its structure, because literature stands for itself.

Furthermore, the researcher uses comparative method. According to Susan Bassnet (Bassnet, 1993, p. 1), comparative literature is a study of the comparison between literature and something else or between literature and something about human expression. Comparative literature is one of the many approaches that exist in study of literature. "Pada hakikatnya setiap penelitian menggunakan langkah membanding-bandingkan sebab hanya dengan langkah itu kita bisa sapai pada pemahaman suatu masalah" (Damono, 2005, p. 1). In the process, this comparison method will compare similarities and differences regarding the topic of study contained in the object of research. This method is used to compare two subjects between two movies, they are Brave (2012) and Moana (2016)..

\section{FINDINGS AND DISCUSSIONS}

The followings are the several findings of this research:

\section{Ordinary World in Brave and Moana Movie}

Merida: I'm the princess. I'm the example. [Merida quickly discards the apple and wipes her mouth with the back of her hand and starts walking towards her parents] I've got duties, responsibilities, expectations. My whole life is planned out, until the day I become, well, my mother. She's in charge of every single day of my life. 
This ordinary world stage only introduces the daily life of the Heroine. From the data above we already know that so many demands that must be fulfilled by Merida as the successor to the kingdom. As a princess, so many activities that must be done and prohibited. She is well educated to be an elegant, polite and graceful princess by her mother. That is an illustration of Merida's daily life. "Another important function of the Ordinary World is to suggest the dramatic question of the story" (Vogler, 2007, p. 88). From the quotes above that shows the daily life of Merida, we can see that her nature was very contrary to what her mother taught. This raises a dramatic question about the Heroine. Will she be able to assume the responsibility of being a queen in the future? What kind of queen? Can she overcome her weaknesses? From this stage raises the curiosity of the audience for the continuation of the story. What problems Merida will face will be known at a next stage.

Next switch to Moana movie. If Merida as the successor to the kingdom, then Moana is the next chief of her village.

Chief Tui: I know, I know. But you don't go out there. It's dangerous. Moana, come on. Let's go back to the village. You are the next great chief of our village of our people.

Tui is Moana's father. From what he said, the audience got new information about the heroine that Moana is the successor to the tribe or people of the island. Means the father is the village head or tribal chief and the next generation who will lead must be Moana. In the first scene we got the information about both heroines. As we already know that both of the heroine on both movies are the next chief or queen.

\section{The Call to The Adventure in Brave and Moana movie}

As mentioned in the previous stage, Merida is the successor daughter of the Dun Broch clan. She has been trained to be a decent Princess. In this stage, Merida suddenly gets news from her parents that she will soon be engaged as in the quote below.

Fergus: Merida... [Fergus hesitates, not knowing what to say] Elinor: The lords are presenting their sons as suitors for your betrothal.

Merida: What?

Elinor: The clans have accepted!

In the data above, Queen Elinor or Merida's mother told Merida that she would soon be engaged to the eldest son of another kingdom. Previously, Queen Elinor received a letter from another clan and it turned out that the contents of the letter were something that made Merida angry. She was angry because her parents did not discuss it before with her. Her parents told Merida shortly after receiving the letter. This became the first and foremost trigger for Heroine to carry out adventures in the future.

Next discuss the stages of call to the adventure in the Moana movie.

Gramma: Go.

Moana: Not Now. I can't.

Gramma: You must! The ocean chose you. Follow the fish hook.

Moana: Gramma...

In adversity and sadness over the death of her grandmother, Moana still had to go to carry out the mandate of her grandmother to save Te Fiti. We can see that Moana as heroine is the source of hope (Jung, 1980, p. 167). Finally she empowers and ventures to really commit to the adventure. Moana persuaded her father to go outside the reef, until her grandmother died, then Moana forced herself to go sailing out of the reef because of carrying out the mandate from her grandmother and no one else could do it besides herself. 


\section{Refusal to The Call in Brave and Moana movie}

In Brave movie there is no refusal to the call stage. That is because the problems that come are inner problems of the heroine herself. Merida felt very uncomfortable when she was forced to have an arranged marriage with a prince and was made a present for a match. She really wants to be understood by her mother and cancel the arranged marriage. So, she will not refuse to go on an adventure to change her mother's decision.

Whereas in the Moana movie, there is a refusal to the call stage.

Gramma: Go.

Moana: Not now. I can't.

Gramma: You must! The ocean chose you. Follow the fish hook.

The rejection of adventure can be a word that indicates that heroine objected to adventure. In this case, Moana objected to the adventure because she did not want to leave her grandmother who was dying. Until finally Moana actually goes outside the reef to find Maui and restore the heart of Te Fiti. It accordance with Allison \& Goethals, "At other times the hero first refuses to undertake the journey but then grows to understand his or her destiny as a hero" (Scott T. Allison, 2011, p. 41).

\section{Meeting with The Mentor in Brave and Moana movie}

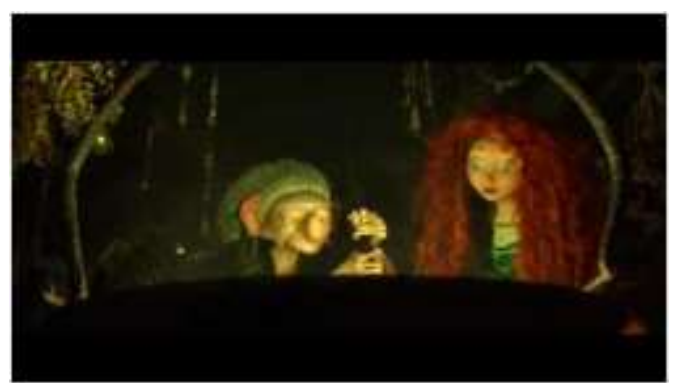

Figure 1. A screenshot from Brave (Min 00.34.51)

In figure 1, it has been ascertained that the old woman is indeed a mentor who gives instructions to Merida as the Heroine to do something. The witch gave a spell on the cake that will be given to Queen Elinor to make her changes as Merida's wants. Now Merida has already met with the mentor who is a witch. "Heroes of mythology seek the advice and help of the witches, wizards, witch doctors, spirits, and gods of their worlds." (Vogler, 2007, p. 119). It was proven in movie that the heroine has passed this meeting with the mentor stage.

The next step is the analysis of the meeting with the mentor in Moana movie. Actually Moana had met the Mentor when she was a child. Her mentor is in the form of magical power from the sea. A mentor is not always a wise old woman, but it can be something magical.

"Folklore is filled with descriptions of heroes meeting magical protectors who bestow gifts and guide them on the journey. We read of the elves who help the shoemaker; the animals who help and protect little girls in Russian fairy tales; the seven dwarfs who give Snow White shelter; or Puss-in-Boots, the talking cat who helps his poor master win a kingdom. All are projections of the powerful archetype of the Mentor, helping and guiding the hero." (Vogler, 2007, p. 118).

Magical protectors mentioned above are also exist in the Moana movie, in figure 2. Since the first meeting, the magical power of the ocean delivered a stone which is the heart of Te Fiti to Moana. From here her grandmother believed that Moana had been chosen by the sea to restore the heart of Te Fiti. 


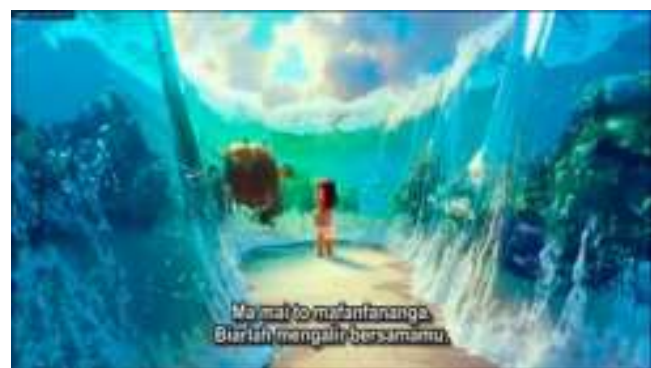

Figure 2. A sceenshot from Moana min. 00.06.21

\section{Crossing the First Threshold in Brave and Moana movie}

After getting a cake that has been given a spell by a witch, then Merida took it to the kingdom and gave it to Queen Elinor or her mother. Shortly after her mother ate the cake, her mother felt something strange. Merida hopes, it is a

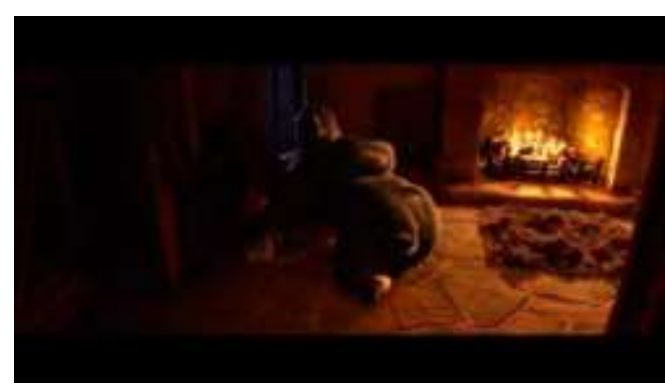

Figure 3. A Screenshot Brave in Min. 00.40.07

reaction from her mother who will change her mind to cancel the arranged marriage. But apparently, it was unexpected that her mother turned into a very large and frightening bear.

This stage is the transition between the ordinary and special world for Merida. She witnessed for herself that her mother turned into a bear with magical power. Indeed, she had previously trusted the world of magic and something magical. But this time, she truly experienced that magical event for real. For Merida as the heroine, this incident is crossing the first threshold stage.

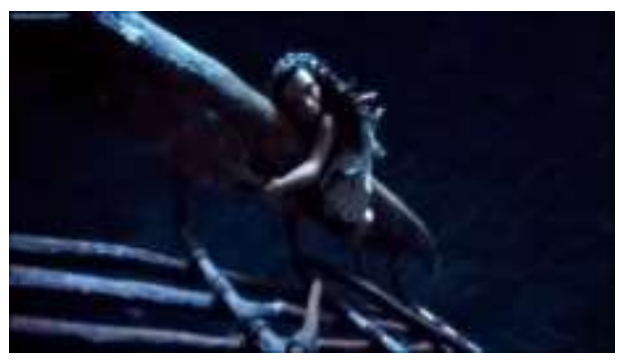

Figure 4. A Screenshot Moana in Min. 00. 34.53

The picture above strongly indicate that Moana is in fear and difficulty. The boat flipped over amid a cheering storm. The light in the picture is the light from lightning. She hugged her ship with a gloomy, panicked expression. This section is part of crossing the first threshold because this part is testing Moana.

That's how the two Heroes went through the crossing the first threshold. Merida through this stage with feelings of regret for having changed her mother into a bear. While 
Moana made it through this stage with a tired body and was found unconscious on an unknown island. This stage is in accordance with what Vogler said, "The passage to the Special World may be exhausting, frustrating, or disorienting" (Vogler, 2007, p. 130).

\section{Test, Allies, Enemies in Brave and Moana movie}

Because Merida has passed through the gate to the special world, at this stage she would face a real adventure.

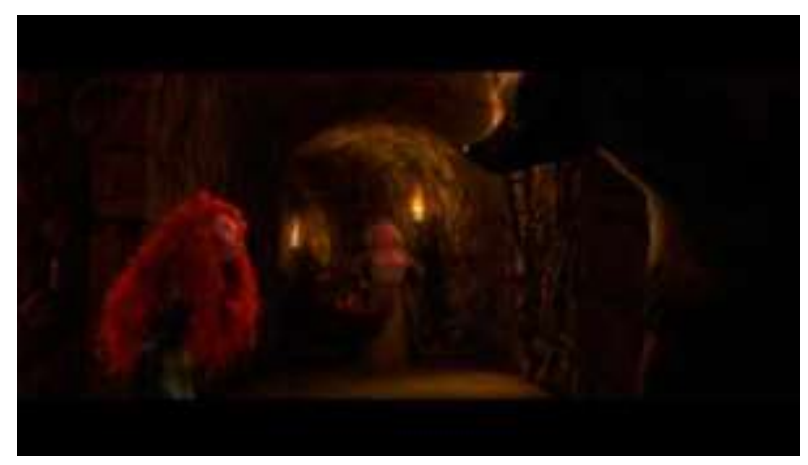

Figure 5. A Screenshot from Brave in Min. 00.42.47

This 'special' world has different feel, different rhythm, different priorities and values, and different rules (Vogler, 2007, p. 136). Special world for Merida is a world of magic, when magic was experienced by Merida to change her mother. Now, her mother has turned into a scary big bear. For Merida's family or for the kingdom, the Bear is their enemy because Merida's father once lost his leg due to a battle with a bear. And now,

Queen Elinor turned into the figure most hated by royal family. While Queen Elinor changed into a bear in her room in the kingdom. That was the first challenge for Merida to get her mother out of the kingdom to find a witch who had changed her mother.

Moana: I got something shiny for ya! [spitting] [grunting]

Tamatoa: The heart of Te Fiti. You can't run from me! Oh, you can. You keep surprising me. [grunting]

Meanwhile one of Moana's test is that they must take Maui's hook. They went to the place where the monsters belong as Maui's hook was there. Arriving there Moana plays a role to lure the Monster and Maui takes the hook. Moana cleverly bait the monster by showing the stone which is the heart of Te Fiti. It turned out that the stone that Moana showed was just a sea stone similar to the heart stone of Te Fiti. Although Moana finally managed to lure the monster and take Maui' s hook, but her actions are full of risks. Even Maui, who clearly has great strength, was overwhelmed by Tomata. But, finally they managed to get out of the place safely. 


\section{Approach to The Inmost Cave in Brave and Moana movie}

The next elements of those movies are the inmost caves. We can see figure 5 in Brave movie:

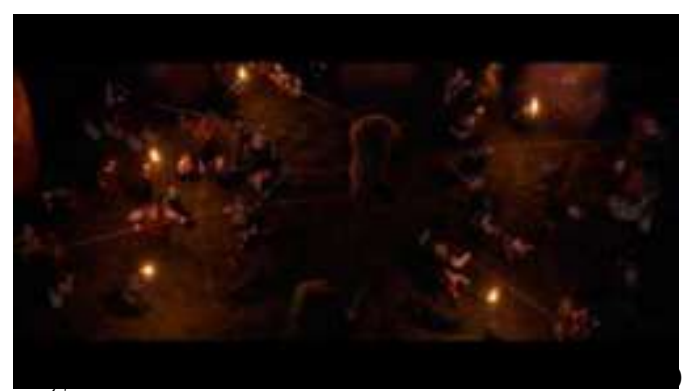

The heroine is facing with something she is afraid of like death. The biggest fear for Merida is not her own death, but the loss of her mother. This stage is when Merida's mother is found by her father and other royal members. They chased after Queen Elinor who ran away and tied her up. When her father and the royal members found the Queen, Queen Elinor was already bound and will be killed by everyone there. Merida immediately draws her sword to protect her mother. In this stage Merida is willing to protect her mother by risking her life.

Next is approach to the inmost cave stage in Moana movie. Moana's courage and determination in approaching Te Ka. Te ka is the form of Te Fiti who lost her heart. She is a hot stone that contains lava liquid.

Maui: What are you doing?

Moana: Finding you a better way in!

Maui: We won't make it!

Merida intends to help Maui by finding a safe way to pass Te Ka. But the road will only endanger them. And sure enough, Te Ka's attack led to the ship they were driving. But Maui managed to hold it with the hook. This incident is included in the approach to the inmost cave stage in accordance with Vogler's theory, "Some heroes boldly stride up to the castle door and demand to be let in. Confident, committed heroes will take this Approach." (Vogler, 2007, p. 144). Merida is brave and very confident that she will succeed, even in fact they were fail. Although she has faced Te Ka, this incident belongs to the approach to the inmost cave because it is still the beginning in approaching Te Ka.

\section{The Ordeal in Brave and Moana movie}

Merida: The second sunrise! [she runs and grabs the tapestry that she's mended and throws it around Elinor, but realizes nothing's happening] Oh, no! I don't understand. I... [Merida begins to cry and kneels in front of Elinor] Oh, mom, I'm sorry. This is all my fault. I did this to you, to us. [she tearfully hugs Elinor] You've always been there for me. You've never given up on me. I just need you back. I want you back, mommy. I love you.

The ordeal stage in Brave movie is when the second sunrise. Here Merida experiences the greatest fear. This is the peak of fear from Merida. Even though all efforts have been made to change her mother, her mother has never returned. She expressed feelings of regret and a deep love for her mother. If the hero in another adventure story passes through this stage by dealing with the most dangerous enemy and death, in this adventure story the heroine is faced with all her regrets because this ordeal stage can be a crisis of the heart (Vogler, 2007, p. 166). Besides, there must be a sense that the situation is getting worse and worse. That's what makes a story dramatic and the audience learns 
who his protagonist truly is (Bernhardt, 2013, p. 22). If her mother does not change into her original form, Merida will lose her mother. Thus, moral heroes evoke powerful emotions from us (Scott T. Allison, 2011, p. 45). That's how Merida passed through the ordeal stage.

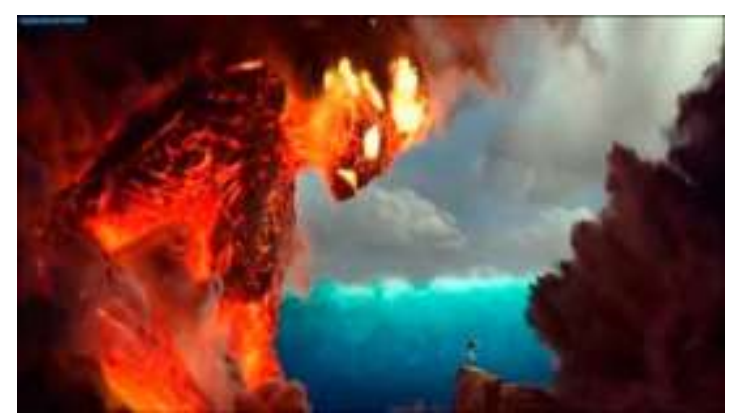

Figure 7. A Screenshot from Moana in Min. 01.29.18

Next is the ordeal stage in Moana movie. This stage is when Moana returns to Te $\mathrm{Ka}$. Moana risked her life to restore Te Fiti's heart. She provoked Te Ka by lifting the heart stone of Te Fiti. Moana asked the ocean to split the ocean to make way for Te Ka come to Moana. Te Ka came very angry and ran, but Moana sang with lyrics that reminded Te Ka of her old self. Though it is still very likely that Te Ka did not return to the form of Te Fiti and fight or even kills Moana. This stage is the most dangerous stage passed by heroine as Vogler said, "Now the hero stands in the deepest chamber of the Inmost Cave, facing the greatest challenge and the most fearsome opponent yet" (Vogler, 2007, p. 155). That's the stage of The Ordeal in Moana movie.

\section{Reward in Brave and Moana movie}

Merida: Mom! You're back! [Elinor hugs Merida and kisses her face repeatedly] You've changed!

Elinor: Oh, darling. We both have. [Elinor kisses Merida again and Fergus comes up running towards them]

In Brave Movie, the reward obtained is self-realization. After her mother changed, Merida felt the peace and warmth of her mother's arms again. Besides the return of Queen Elinor and her three younger siblings into human form, Merida also gained important values from this incident such as self-realization and becoming wiser in her life. This event finally had a happy ending, her mother turned back into a human and Merida gained her mother's trust to live freely and not be in an arranged marriage. Merida is now learning from her mistakes and can live fully herself. In addition, she learned an important lesson that her family is more important than her own ego.

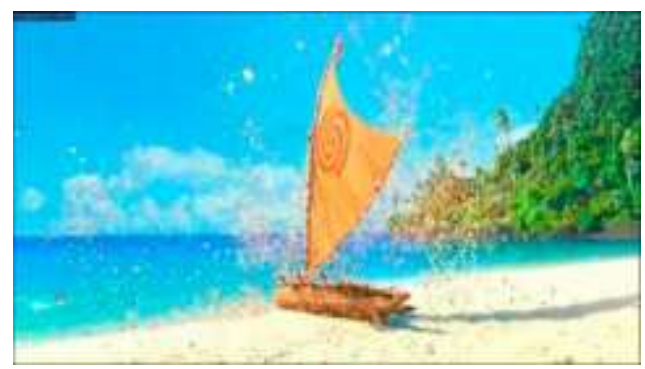

Figure 7. A Screenshot from Moana in Min 01.32.02 
While the reward in the Moana movie is when Te Fiti gives a new sailing boat to Moana so that she can return to her island. The award obtained is the result of the efforts and sacrifices the heroine. Moana sacrificed her boat being destroyed and damaged by Te Ka's attack. Actually, with the return of the heart of Te Fiti, they will benefit each other. Te Fiti returns to its original form, Maui will be known as a hero and Moana will get the Motunui island as it was before without darkness lurking.

\section{Return with Elixir in Brave and Moana movie}

This stage in Brave Movie is an Epilogue which explains that Merida has gained a higher understanding of herself and her life.

Merida: [voice over] Some say fate is beyond our command, but I know better. Our fate lives within us. You just have to be brave enough to see it. [we see Merida rides off through the forest with her Elinor, making their bond stronger]

The data above shows that Merida has gotten what she has been looking for, her fate. She learned that, so far, her fate lives within her. She had not been aware that something she was looking for was in herself, she just had to be more daring to find out.

\section{Villager 1: She's back! \\ Villager 2: Moana! [Pua squealing] \\ Moana: Pua! Oh! [laughs] Villager 1: \\ Moana! [clucking]}

Villager 2: Welcome home! [clucking] [villagers cheering] Next in the Moana movie. This stage is a scene where Merida returns to Motunui Island. She was so welcomed by her parents and villagers. Merida returns with her sailing experience and makes the island return to normal. The island is fertile again and not hit by darkness again. The Elixir that Moana received was in the form of returning the island of Motunui to its original state. The heroine can get elixir either literal or metaphorical. Merida in Brave movie gets a methaporical elixir. She gets love, trust and new values in her life. Whereas Moana received elixir literally. She got an elixir in the form of the healing of her island which was stiken by darkness.

\section{CONCLUSIONS}

In this research, the researcher concludes that the heroine in the Brave and Moana movie through the stage of journey there were 9 and 10 stages. If seen from the theory of hero's journey from Christopher Vogler, the heroine in Brave movie goes through 9 stages of hero's journey. While Moana movie passed 10 stages of the hero's journey. There is one difference in the two movies when viewed from the heroine's journey. Brave movie does not go through the refusal to the call stage. That is because the problems that come are the inner problems of the heroine herself. Merida feels very uncomfortable when she was forced to have an arranged marriage with a prince and was made a present for a match. She really wants to be understood by her mother and cancel the arranged marriage. So, she will not refuse to go on an adventure to change her mother's decision. While the heroine in Moana movie goes through the refusal to the call stage several times before actually going on an adventure. While the similarity is that both movies do not go through the road back stage and the resurrection stage. That's because both movies chosen by researchers are films made for children and teenagers, which means the complexity of the film does not have a high level of complexity. So, the plot and the heroine stage will be simpler than other adventure stories. 


\section{REFERENCES}

Abrams, M. H. (2009). A Glossary of Literary Terms Ninth Edition. Wadsworth Cengage Learning.

Bassnet, S. (1993). Comparative Literature: A Critical Introduction. Blackwell Publishers Ltd.

Bernhardt, W. (2013). Perfecting Plot: Charting the Hero's Journey. Babylon Books.

Cawelti, J. G. (1976). Adventure, Mystery, and Romance. The University of Chicago Press.

Damono, S. D. (2005). Pegangan Penelitian Sastra Bandingan. Pusat Bahasa Departemen Pendidikan Nasional.

Hourihan, M. (1997). Deconstructing The Hero: Literary Theory and Children's Literature. Routledge.

Jung, C. G. (1980). Archetypes and The Collective Unconscious. Princeton University Press.

Nurrachman, D. (2017). Introduction to Criticism. Pustaka Aura Semesta.

Scott T. Allison, G. R. G. (2011). Heroes: What They do \& Why we need them. Oxford University Press.

Vogler, C. (2007). The Writer's Journey: Mythic Structure for Writers (third editions. Michael Wiese Productions. 